\title{
Management of Auditory Neuropathy Spectrum Disorder
}

\author{
Sung Wook Jeong, Lee-Suk Kim \\ Department of Otolaryngology, Dong-A University College of Medicine, Busan, Korea
}

\section{청각신경병증의 치료}

정 성 욱·김 리 석

동아대학교 의과대학 이비인후과학교실

\begin{abstract}
Auditory neuropathy spectrum disorder (ANSD) is a hearing disorder characterized by an absent or severely abnormal auditory brainstem response (ABR) with preservation of cochlear microphonics or otoacoustic emissions (OAE). These findings suggest that outer hair cell is normal but function of inner hair cell or auditory nerve is impaired. ANSD is a disorder in which behavioral threshold measures do not match with other measures of auditory function such as ABR data and speech discrimination scores. The patients with ANSD can have various hearing thresholds from normal to profound degree, but speech discrimination is very poor and out of proportion to pure tone loss. Therefore conventional amplification is of little benefit to improve speech-language ability. Frequency-modulation system to enhance signal-to-noise ratio can help in situations with background noise like classroom, car, and restaurant. Visual communication is also helpful. Cochlear implantation is a promising tool for habilitation of patients with ANSD. Most patients who receive cochlear implantation show significant improvements in speech perception abilities and good results in electrical ABR. However some very young children with ANSD can recover during first 12-18 months of life and develop speech and language normally without any intervention. Therefore cochlear implantation should be considered after the persistent ANSD is confirmed through repeated assessment using electrophysiological measures and behavioral hearing tests.
\end{abstract}

Key Words: Auditory neuropathy spectrum disorder, Cochlear implantation, Auditory brainstem response, Otoacoustic emission.

Received: February 21, 2016 / Accepted: March 10, 2016

Correspondence: Lee-Suk Kim, Department of Otolaryngology, Dong-A University College of Medicine, 26 Daesingongwon-ro, Seo-gu, Busan 49201, Korea Tel: +82-51-240-5428 / Fax: +82-51-253-0712 / E-mail: klsolkor@chol.com

\section{INTRODUCTION}

청각신경병증은 감각신경성난청의 일종으로, 이음향방사 (otoacoustic emission) 검사에서는 정상 반응을 보이지만 청성 뇌간반응(auditory brainstem response) 검사에서는 반응이 나 타나지 않거나 매우 비정상적인 반응을 보이는 질환이다(Starr et al., 1996; Kim, 2008). 이는 외유모세포의 기능은 보존되어 있으나, 내유모세포에서 제1형 청신경세포로 이어지는 청각전 달로에 이상이 있음을 시사하는 소견이다. 일반적인 감각신경 성난청의 경우, 원인 병변이 외유모세포를 우선적으로 침범하 기 때문에 외유모세포의 기능을 반영하는 이음향방사는 나타 나지 않고 청성뇌간반응검사에서는 유모세포의 손상 정도에 비 례하여 그 역치가 증가하는 소견을 보이는 것에 대조된다.
청각신경병증은 1995년 프랑스 리옹에서 열린 제 14차 국제 청각유발반응학회에서 Arnold Starr가 'auditory neuropathy' 라는 병명으로 처음 소개하였고, 같은 해 Sininger et al.(1995) 이 3 명의 환자를 문헌을 통해 처음 보고하였다. 국내에서는 Kim et al.(2003)이 1998년 제 72차 대한이비인후과학회 학술 대회에 3 명의 청각신경병증 환자를 보고하면서 처음 소개되었 다. 청각신경병증은 병변의 위치, 청각적 수행력, 질환의 경과 등이 매우 다양한 특징을 가지고 있기 때문에 최근에는 auditory neuropathy spectrum disorder (ANSD)라는 병명이 널리 사용되고 있다.

청각신경병증의 임상 양상은 매우 다양하다. 청력 역치는 정 상에서 심도 난청까지 다양하게 나타날 수 있고, 난청은 영구적 인 경우가 많으나 자연 호전되거나 변동하는 경우도 있다. 유 
전, 청신경의 선천적 이상, 후천적 대사 이상 등 다양한 원인에 의해 발생하며, 청신경 외 다른 말초신경을 침범하는 경우도 있 다. 그러나 모든 환자에 있어서 한 가지 공통적인 증상은 어음 인지도가 매우 나쁘다는 점이며, 배경 소음이 있는 경우 어음인 지도는 더욱 저하된다.

일반적인 감각신경성난청의 경우 청력역치의 상승 정도에 비 례하여 어음인지도가 저하되기 때문에 청력 역치와 어음인지 도가 크게 나쁘지 않으면 보청기가 도움이 되며, 청력 역치와 어음인지도 모두가 매우 나쁜 경우에는 인공와우이식을 통해 말소리를 들을 수 있다. 그러나 청각신경병증의 경우 청력 역치 와 무관하게 어음인지도가 매우 나쁜 특징을 가지고 있어 청각 재활에 어려움이 있다. 이에 청각신경병증의 치료에 대해 살펴 보고자 한다.

\section{청각신경병증의 치료를 위한 우선적인 고려 사항}

청각신경병증의 발병 연령은 출생시부터 60 세에 이르기까지 다양하지만, 대부분은 출생시 혹은 신생아기에 발병한다 (Sininger \& Oba, 2001). 신생아 난청의 치료에 있어서 가장 중 요한 점은 조기 치료인데, 이는 신생아청각선별검사의 보편화로 인해 가능하게 되었다. 난청을 가진 신생아는 생후 3 개월 이내 에 확진을 받고 6 개월 이내에 보청기를 이용한 조기 치료를 시 작하며, 심도 난청이 있는 경우에는 1 세 전후에 인공와우이식 을 받음으로서 정상에 가까운 말언어능력을 습득할 수 있다. 그러나 청각신경병증을 가진 신생아의 경우 두 가지 이유로 인 해 조기 중재에 어려움이 있다. 첫 번째 이유는 청력 역치가 정 상일 수 있다는 점이다. 모든 청각신경병증 환자가 공통적으로 어음인지도는 매우 저하되어 있으나, 청력 역치는 정상에서 심 도 난청까지 다양하게 나타날 수 있다. 그런데 모든 경우에 청 성뇌간반응이 나타나지 않기 때문에, 청성뇌간반응검사로는 청 력 역치를 알 수 없어 영아기 환자의 치료 방침을 정하는데 어 려움이 있다. 두 번째 이유는 자연 회복의 가능성이 있다는 점 이다. Berlin et al.(2003)의 보고에 의하면 100 명의 청각신경병 증 환자 중 7명에서 비록 청성뇌간반응은 나타나지 않고 소음 환경에서 불편은 있으나 특별한 치료 없이 정상적인 말언어 발 달을 이룰 수 있었으며, 이러한 회복은 생후 1 세 6 개월 이전에 시작되었다고 한다. Raveh et al.(2007)은 19명의 소아 환자 중 4명에서 생후 1 년 안에 청력의 자연 호전이 있었다고 보고하였 고, Attias \& Raveh(2007)는 신생아청각선별검사를 통해 청각 신경병증을 진단받은 5 명의 영아를 대상으로 반복적인 청력검 사를 시행한 결과 생후 12 개월 이내에 청성뇌간반응과 청력역 치가 정상으로 회복되었다고 보고하였다. 따라서 청각신경병증 을 가진 영아기 환자에서는 정기적인 청력 검사를 통해 자연
회복 여부를 면밀히 관찰하여 치료 방침에 반영하여야 한다.

\section{청각신경병증의 치료}

청각신경병증의 주 증상은 "어음인지도가 크게 저하된 난청" 이기 때문에 보청기, FM 보청기, 그리고 인공와우이식이 치료 방법으로 고려될 수 있다.

\section{보청기}

보청기는 단순히 청력 역치만을 낮추기 때문에 청각신경병증 을 가진 아동의 말언어능력을 향상시키는 데는 큰 도움이 되지 못한다. 청각신경병증 환자는 개개의 청신경섬유에서 방출되는 활동전위의 동시성(synchrony)의 소실로 인해 빠르게 변하는 소 리 신호를 처리하는 능력인 시간 정보처리(temporal processing ability)가 저하되어 있다(Zeng et al., 1999). 사람의 말소리와 같이 빠르게 변하는 소리 신호를 실시간으로 처리하지 못하면 소리는 들었으나 무슨 말인지 알아듣지 못하는 현상, 즉 어음 인지도가 저하되는 현상이 초래된다. 보청기는 소리를 증폭하 여 청력역치를 개선할 뿐 시간정보 처리를 향상시키지 못하기 때문에 어음인지도가 개선되지 않으며, 따라서 말언어 발달에 큰 도움이 되지 못한다. 다만 보청기가 어음탐지역치(speech detection threshold)를 낮출 수는 있기 때문에 청력 역치가 상 승된 경우에는 보청기를 사용하되, 출력을 가능한 줄여 유모세 포가 손상되지 않도록 하는 것이 좋다(Sininger et al., 1995). 청 각신경병증 아동은 청력 역치가 정상일 수 있고 청성뇌간반응 검사로 청력 역치를 알 수 없기 때문에, 시각강화 청력검사와 같 은 행동반응 청력검사를 통해 청력 역치를 확인한 후 보청기 사용 여부와 보청기 이득을 결정하여야 한다.

\section{FM 보청기}

어음인지도의 저하는 소음 환경에서 더욱 심해진다. 따라서 학교, 승용차 안, 식당 등 배경 소음이 있는 공간에서는 FM 보 청기를 사용하는 것이 큰 도움이 될 수 있다. 하지만 FM 보청기 는 조용한 환경에서의 어음인지도가 어느 정도 보존된 환자에 서 도움이 될 수 있기 때문에 모든 환자에 적용되지는 않는다.

\section{인공와우이식}

인공와우이식은 와우의 기능이 상실되었을 때 와우를 대체 하는 인공와우를 이식하는 수술이다. 따라서 와우 병변으로 인 한 난청인 경우만 이식 수술의 대상이 될 수 있으며, 청신경의 병변으로 인한 난청은 인공와우이식의 주된 금기로 여겨져 왔 다. 청각신경병증은 이음향방사검사에서는 정상 반응을 보이고 청성뇌간반응 검사에서는 무반응인 점으로 미루어 청신경의 
병변이 주 원인으로 생각되었기 때문에 과거에는 인공와우이식 이 적극적으로 시행되지 못했다. 특히 초기에 시행했던 인공와 우이식의 결과가 극히 부진한 것으로 보고되면서 청각신경병증 에서 인공와우이식은 널리 시행되지 못하였다(Miyamoto et al., 1999; Rance et al., 1999). 하지만 내유모세포의 병변이나 내유 모세포와 제1형 청신경세포를 연결하는 시냅스에 국한된 병변 으로도 청각신경병증이 발생할 수 있다는 사실이 증명되면서 인공와우이식이 적극적으로 시행되기 시작하였다(Amatuzzi et al., 2001; Varga et al., 2003). 내유모세포나 시냅스의 병변은 인공와우가 작동하는데 아무런 제한이 되지 못하기 때문이다. 실제로 Gibson \& Sanli(2007)는 인공와우이식을 받은 60명의 소아 청각신경병증 환자 중 75\%에서, Teagle et al.(2010)은 인 공와우이식을 받은 청각신경병증 환자의 약 $50 \%$ 에서, 그리고 Jeong et al.(2007)은 이식 아동의 약 65\%에서 우수한 말지각 력을 보여주었다고 보고하였다.

이와 같이 인공와우이식이 청각신경병증의 좋은 치료법이 될 수 있지만, 시행 여부는 다음의 세 가지 사항을 신중히 고려한 후 결정하여야 한다. 첫째는 앞서 기술한 바와 같이 모든 청각 신경병증 환자가 인공와우이식으로 충분한 도움을 받는 것은 아니라는 사실이다. 인공와우이식으로 충분한 도움을 받지 못 하는 25 50\%에 해당하는 환자를 수술 전에 미리 알아내어 그 정보를 환자와 보호자에게 제공할 필요가 있다. 청각신경병증 환자의 인공와우이식 후 예후를 결정하는 요인이 명확히 밝혀 져 있지는 않지만 다양한 연구의 결과들을 종합해 보면, 청신 경의 병변을 시사하는 소견을 보이는 경우 이식 후 결과가 부 진하고 내유모세포나 시냅스의 병변을 시사하는 소견이 있는 경우 이식 후 결과가 우수하다. 인공와우는 내유모세포와 시냅 스를 건너뛰어 청신경을 직접 전기자극하는 장치이므로, 내유 모세포나 시냅스의 병변은 인공와우가 작동하는데 영향을 미 치지 않기 때문이다. 청신경의 병변을 시사하는 소견에는 난청 외에 말초신경병증을 동반한 경우, MRI 검사에서 와우신경부 전(cochlear nerve deficiency)을 가진 경우가 해당한다. 특히 와우신경부전은 선천성 청각신경병증의 주요 원인 중 하나인 데, 많게는 선천성 청각신경병증의 약 $30 \%$ 에서 동반되는 것으 로 보고되었으며, 이 경우 인공와우이식의 효과가 매우 부진한 것으로 알려져 있어 특히 주의를 요한다(Colletti et al., 2013). 내유모세포의 병변을 시사하는 소견에는 MRI 검사에서 정상 적인 와우신경을 가진 경우, $\mathrm{OTOF}$ 유전자 돌연변이가 있는 경 우 등이 해당한다. 특히 OTOF 유전자의 돌연변이로 인한 청각 신경병증은 인공와우이식의 결과가 매우 우수한 것으로 보고 되고 있다(Loundon et al., 2005). OTOF 유전자는 내유모세포 와 제 1형 청신경을 연결하는 시냅스에서 신경전달물질의 분비 에 관여하는데, 돌연변이가 생길 경우 신경전달물질의 분비 장
애가 발생하고 이로 인해 청각신경병증의 검사소견에 부합하는 난청이 발생한다(Varga et al., 2003). 이와 같이 청각신경병증 환자에서 인공와우이식을 시행할 경우에는 MRI 검사와 유전 학적 검사를 시행하여 이식 대상자 선정과 기대치 조절에 필요 한 정보를 얻는 것이 좋다(Jeong \& Kim, 2013).

인공와우이식에 앞서 두 번째 고려할 사항은 신생아의 청각 신경병증은 비록 드물기는 하지만 생후 12 18개월 이내에 자연 회복의 가능성이 있다는 점이다. 따라서 청각신경병증으로 진 단된 신생아 혹은 영아의 경우에는 적어도 생후 12 개월까지는 청성뇌간반응검사를 포함한 청력검사를 주기적으로 시행하여 자연 회복이 없다는 사실을 반드시 확인한 후 수술 여부를 결 정하여야 한다.

인공와우이식에 앞서 마지막으로 고려할 사항은 청력 역치이 다. 청각신경병증을 가진 아동은 청력이 정상에서 심도 난청까 지 다양하게 나타날 수 있다. 심도 난청이면서 말언어발달의 진 전이 없는 경우 인공와우이식을 결정하는데 어려움이 없으나, 청력 역치가 정상이거나 중등도 난청 이하인 경우에는 인공와 우이식을 시행하는 것이 과연 정당한 것인지 판단하기 어려울 수 있다. 청각신경병증의 주요 병태생리는 단순한 청력 역치의 상승이 아니라 각각의 청신경섬유에서 방출되는 활동전위의 비동기화(dys-synchrony)에 기인한 어음인지도의 저하이다. 인 공와우를 통한 전기 자극은 말소리 자극에 비해 더욱 동기화된 활동전위를 유발할 수 있기 때문에 어음인지도의 개선에 기여 할 수 있다. 따라서 청각신경병증에서 인공와우이식을 결정하 는 기준은 청력 역치(detection threshold)가 아닌 어음인지도 (discrimination)가 되어야 한다. $\operatorname{Hood}(2015)$ 의 보고에 따르면, $1 \sim 8 \mathrm{kHz}$ 영역에서 정상 청력 역치를 가지고 있으나 어음인지 도가 8 10\%(소음 하 어음인지도 0\%)로 저하된 15세 청각신경병 증 아동에게 인공와우이식을 시행한 결과 어음인지도가 $96 \%$ (+10 dB SNR에서 74\%)로 상승되었다고 하였다.

\section{시각을 이용한 의사소통 방법}

부족한 어음인지도를 보완하기 위해 보청기나 FM보청기의 사용과 함께, 구화의 문법구조에 부합하는 signed language나 cued speech 등의 시각을 이용한 의사소통 방법을 보조적으 로 이용하면 말언어 발달에 도움이 될 수 있다(Berlin et al., 1998). 인공와우이식을 시행한 경우에도 말지각력이 부족한 경 우에는 시각을 이용한 의사 소통 방법을 함께 사용하는 것이 좋다(Hood, 2015).

\section{CONCLUSION}

청각신경병증은 청성뇌간반응 검사에서 반응이 없는 난청 
아동의 약 $10 \%$ 를 차지하는 드물지 않은 질환이다. 청각신경병 증 환자의 임상 양상이 매우 다양하기 때문에, 개개인의 청각적 상황에 따라 치료 방침을 결정하여야 한다. 시각을 보조적으로 이용한 의사소통 방법, 보청기, FM 보청기, 그리고 인공와우이 식 등의 치료 방법들을 아동의 상태에 따라 적기에 적절히 적용 하여 최선의 말언어발달을 도모할 수 있도록 하여야 할 것이다.

\section{중심 단어 : 청각신경병증·인공와우이식·청성뇌간반응·이음 향방사.}

\section{REFERENCES}

Amatuzzi, M. G., Northrop, C., Liberman, M. C., Thornton, A., Halpin, C., Herrmann, B., et al. (2001). Selective inner hair cell loss in premature infants and cochlea pathological patterns from neonatal intensive care unit autopsies. Archives of Otolaryngology-Head and Neck Surgery, $127,629-636$

Attias, J. \& Raveh, E. (2007). Transient deafness in young candidates for cochlear implants. Audiology and Neurotology, 12, 325-333.

Berlin, C. I., Bordelon, J., Patti, S. J., Wilensky, D., Hurley, A., Kluka, E., et al. (1998). Reversing click polarity may uncover auditory neuropathy in infants. Ear and Hearing, 19, 37-47.

Berlin, C. I., Hood, L., Morlet, T., Rose, K., \& Brashears, S. (2003). Auditory neuropathy/dys-synchrony: diagnosis and management. Mental Retardation and Developmental Disabilities Research Reviews, 9(4), 225231.

Colletti, L., Wilkinson, E. P., \& Colletti, V. (2013). Auditory brainstem implantation after unsuccessful cochlear implantation of children with clinical diagnosis of cochlear nerve deficiency. Annals of Otology, Rhinology and Laryngology, 122(10), 605-612.

Gibson, W. P. R., \& Sanli, H. (2007). Auditory neuropathy: an update. Ear and Hearing, 28(2), 102S-106S.

Hood, L. J. (2015). Auditory neuropathy/dys-synchrony disorder: diagnosis and management. Otolaryngologic Clinics of North America, 48(6), 1027-1040.
Jeong, S. W. \& Kim, L. S. (2013). Auditory neuropathy spectrum disorder: predictive value of radiologic studies and electrophysiologic tests on cochlear implant outcomes and its radiologic classification. Acta OtoLaryngologica, 133(7), 714-721.

Jeong, S. W., Kim, L. S., Kim, B. Y., Bae, W. Y., \& Kim, J. R. (2007). Cochlear implantation in children with auditory neuropathy: outcomes and rationale. Acta Oto-Laryngologica, 127(S558), 36-43.

Kim, L. S. (2008). Auditory neuropathy. Korean J Audiol, 12, 1-9.

Kim, L. S., Jung, S. W., Lee, S. H., \& Heo, S. D. (2003). Auditory neuropathy: a report of three cases. Korean Journal of Otolaryngology-Head and Neck Surgery, 46(10), 874-881.

Loundon, N., Marcolla, A., Roux, I., Rouillon, I., Denoyelle, F., Feldmann, D., et al. (2005). Auditory neuropathy or endocochlear hearing loss? Otology and Neurotology, 26(4), 748-754.

Miyamoto, R. T., Kirk, K. H., Renshaw, J., \& Hussain, D. (1999). Cochlear implantation in auditory neuropathy. The Laryngoscope, 109(2), 181185.

Rance, G., Beer, D. E., Cone-Wesson, B., Shepherd, R. K., Dowell, R. C., King, A. M., et al. (1999). Clinical findings for a group of infants and young children with auditory neuropathy. Ear and Hearing, 20(3), 238.

Raveh, E., Buller, N., Badrana, O., \& Attias, J. (2007). Auditory neuropathy: clinical characteristics and therapeutic approach. American Journal of Otolaryngology, 28(5), 302-308.

Sininger, Y. \& Oba, S. (2001). Auditory neuropathy: A new perspective on hearing disorders (pp. 15-35). San Diego, CA: Singular.

Sininger, Y. S., Hood, L. J., Starr, A., Berlin, C. I., \& Picton, T. W. (1995). Hearing loss due to auditory neuropathy. Audiology Today, 7(2), 10-13.

Starr, A., Picton, T. W., Sininger, Y., Hood, L. J., \& Berlin, C. I. (1996). Auditory neuropathy. Brain, 119(3), 741-754.

Teagle, H. F., Roush, P. A., Woodard, J. S., Hatch, D. R., Zdanski, C. J., Buss, E., et al. (2010). Cochlear implantation in children with auditory neuropathy spectrum disorder. Ear and Hearing, 31(3), 325-335.

Varga, R., Kelley, P. M., Keats, B. J., Starr, A., Leal, S. M., Cohn, E., et al. (2003). Non-syndromic recessive auditory neuropathy is the result of mutations in the otoferlin (OTOF) gene. Journal of Medical Genetics, 40(1), 45-50.

Zeng, F. G., Oba, S., Garde, S., Sininger, Y., \& Starr, A. (1999). Temporal and speech processing deficits in auditory neuropathy. Neuroreport, 10(16), 3429-3435. 